\title{
Konkurencyjność widziana przez pryzmat kultury organizacyjnej przedsiębiorstw - studium teoretyczne
}

\author{
Dr Michał Adam Leśniewski \\ Krakowska Akademia im. Andrzeja Frycza Modrzewskiego \\ Wydział Zarządzania i Komunikacji Społecznej
}

Człowiek wymaga poznania, Człowiek podstawa organizacji, Poznanie organizacji to właściwy człowiek, na którym możesz się oprzeć.

Michał Adam Leśniewski ${ }^{1}$

\section{Wprowadzenie}

Do rozwoju przedsiębiorstwa (organizacji) w warunkach gospodarki rynkowej konieczne jest kształtowanie konkurencyjności, rozumianej jako ogół wszystkich czynników znajdujących się w otoczeniu ${ }^{2}$ wewnętrznym i zewnętrznym organizacji, przyczyniających się ostatecznie do osiągnięcia przewagi konkurencyjnej. Takie spojrzenie na konkurencyjność daje podstawy do kierunkowego myślenia, że to, co tworzy przedsiębiorstwo, staje się jego konkurencyjnością. Z szerokiego spojrzenia na konkurencyjność można wyprowadzić szczegółowe ujęcie konkurencyjności, widzianej przez pryzmat kultury organizacyjnej, czyli stanowiącej konkurencyjność kulturową przedsiębiorstw³ ${ }^{3}$, wpisanej w konkurencyjność miękką4.

1 M.A. Leśniewski, Człowiek Konkurencyjności - model koncepcyjny, [w:] M. Budzanowska-Drzewiecka, K. Czernek (red.), Kierunki ewolucji nauk o zarzq̨dzaniu, Wydawnictwo Uniwersytetu Jagiellońskiego, Kraków 2018, s. 123.

2 Otoczenie w literaturze przedmiotu jest również określane mianem środowiska.

3 M.A. Leśniewski, Konkurencyjność kulturowa przedsiębiorstw. Studium teoretyczno-empiryczne, Wydawnictwo Uniwersytetu Jana Kochanowskiego w Kielcach, Kielce 2020.

4 M.A. Leśniewski, Konkurencyjność miękka przedsiębiorstw, Wydawnictwo Difin, Warszawa 2015. 
Konkurencyjność kulturową można rozpatrywać dwukierunkowo, tj.:

- od konkurencyjności do kultury organizacyjnej oraz

- od kultury organizacyjnej do konkurencyjności.

W niniejszym opracowaniu został przyjęty pierwszy kierunek. W czynnikach konkurencyjności znajduje się kultura organizacyjna (czynnik miękki), która stanowi czynnik kierunkujący konkurencyjność do konkurencyjności kulturowej. Takie spojrzenie na konkurencyjność daje podstawy do myślenia, że konkurencyjność może być budowana i kształtowana na podstawie kultury organizacyjnej, gdzie w centrum zainteresowania jest człowiek, będący sprawcą wszelkich działań, twórcą rozwiązań w przedsiębiorstwie. Można stwierdzić, że człowiek jest początkiem i końcem organizacji - jakich ludzi zatrudniasz, taką masz organizację. Kultura osobista pracownika kształtuje kulturę organizacyjną danego przedsiębiorstwa, czyli człowiek jest kulturotwórczy, jest źródłem kultury organizacyjnej.

Celem opracowania jest przedstawienie problemu konkurencyjności widzianej przez pryzmat kultury organizacyjnej. Powstało ono na podstawie studium literatury przedmiotu $\mathrm{z}$ zastosowaniem metody interpretacji.

\section{Konkurencyjność jako problem jakości człowieka w organizacji}

Funkcjonowanie i rozwój każdej organizacji oparte są tylko i wyłącznie na człowieku i tym, co sobą reprezentuje. Jest on inicjatorem i realizatorem procesów zachodzących w organizacji i poza nią. Z punktu widzenia zarządzania człowiek w organizacji staje się pracownikiem - wyróżnia się tu dwa główne układy:

- podwładny (pracownik wykonawczy) i

- przełożony (pracownik nadzorująco-kontrolujący, czyli menedżer).

W analizie procesu zarządzania najważniejszą osobą jest menedżer (pracownik nadzorująco-kontrolujący), ale bez pracowników wykonawczych nie mógłby on, w całym tego słowa znaczeniu, zarządzać organizacją. Zasadność pracy menedżera wynika bezpośrednio $\mathrm{z}$ tego, jakich podwładnych ma pod sobą. Na organizację w aspekcie człowieka można spojrzeć dwojako, tzn. przez pryzmat ilości i jakości pracowników wykonawczych i pracowników nadzorująco-kontrolujących (menedżerów). W niniejszym opracowaniu został przyjęty jakościowy obraz pracowników - zarówno wykonawczych, jak i nadzorująco-kontrolujących. Jakość menedżera i jakość pracowników wykonawczych stanowi o sukcesie bądź porażce organizacji ${ }^{5}$.

5 M. Bratnicki, Dynamizowanie procesu zarzq̨dzania: organizacyjny pierwowzór przedsiębiorczości, [w:] Dynamika zarządzania organizacjami. Paradygmaty - metody - zastosowania: księga pamiątkowa wydana z okazji 50-lecia pracy naukowej prof. zw. dr. hab. Jerzego Rokity, 
W odniesieniu do konkurencyjności w koncepcji Leśniewskiego funkcjonują dwa podstawowe pojęcia, komplementarne względem siebie, tj. generowanie konkurencyjności i kształtowanie konkurencyjności. Generowanie konkurencyjności to proces tworzenia czynników konkurencyjności, a kształtowanie konkurencyjności to proces kierunkowania wygenerowanych czynników w określony układ elastyczności ${ }^{6}$. Przykłady takiego układu to konkurencyjność miękka, konkurencyjność twarda czy konkurencyjność jakościowa i konkurencyjność ilościowa. Należy pamiętać, że prezentowane układy konkurencyjności mogą występować samodzielnie, jak na przykład konkurencyjność miękka7, lub w postaci mieszanej, na przykład konkurencyjność twardo-miękka czy jakościowo-ilościowa. Zarówno proces generowania, jak i kształtowania konkurencyjności stanowią całościowy obraz konkurencyjności organizacji. Każdy z tych procesów wnosi określoną wartość do organizacji. Jeśli jeden z procesów ${ }^{8}$ jest słabo rozwinięty, będzie to miało wpływ na ostateczną postać konkurencyjności ${ }^{9}$.

Zaangażowanie menedżera i pracownika wykonawczego w konkurencyjność opiera się głównie na szeroko pojętym procesie humanistyczno-filozoficznym, czyli procesie myślenia, świadomości zaangażowania w rozwój indywidualny i organizacyjny (świadomości rozwoju), kreatywnym podejściu do życia oraz umiejętności logicznego łączenia różnych czynników w jedną całość (umiejętność logicznego łączenia). Dzięki myśleniu, świadomości rozwoju, kreatywności oraz umiejętności logicznego łączenia menedżer może proaktywnie, jako decydent zarządzania, generować i kształtować konkurencyjność (zarządzanie konkurencyjnością). Rysunek 1 przedstawia koncepcję Leśniewskiego dotyczącą podstawowych atrybutów człowieka-menedżera i człowieka-pracownika wykonawczego, umożliwiających generowanie i kształtowanie konkurencyjności organizacji w osiągnięciu przewagi konkurencyjnej ${ }^{10}$.

Wydawnictwo Akademii Ekonomicznej im. Karola Adamieckiego w Katowicach, Katowice 2007, s. 107-121.

6 M.A. Leśniewski, Konkurencyjność przedsiębiorstw. Wybrane problemy, Towarzystwo Naukowe Organizacji i Kierownictwa „Dom Organizatora”, Toruń 2011; M.A. Leśniewski, Konkurencyjność miękka..., s. 127.

7 M.A. Leśniewski, Konkurencyjność miękka..., s. 127.

8 W. Czakon, Sieci w zarzqdzaniu strategicznym, Wolters Kluwer Polska, Warszawa 2012.

$9 \quad$ Ł. Sułkowski, Kulturowe procesy zarzqdzania, Wydawnictwo Difin, Warszawa 2012; S. Stańczyk, Nurt kulturowy w zarzq̨dzaniu, Wydawnictwo Uniwersytetu Ekonomicznego we Wrocławiu, Wroctaw 2008.

10 M.A. Leśniewski, Człowiek Konkurencyjności..., s. 127. 


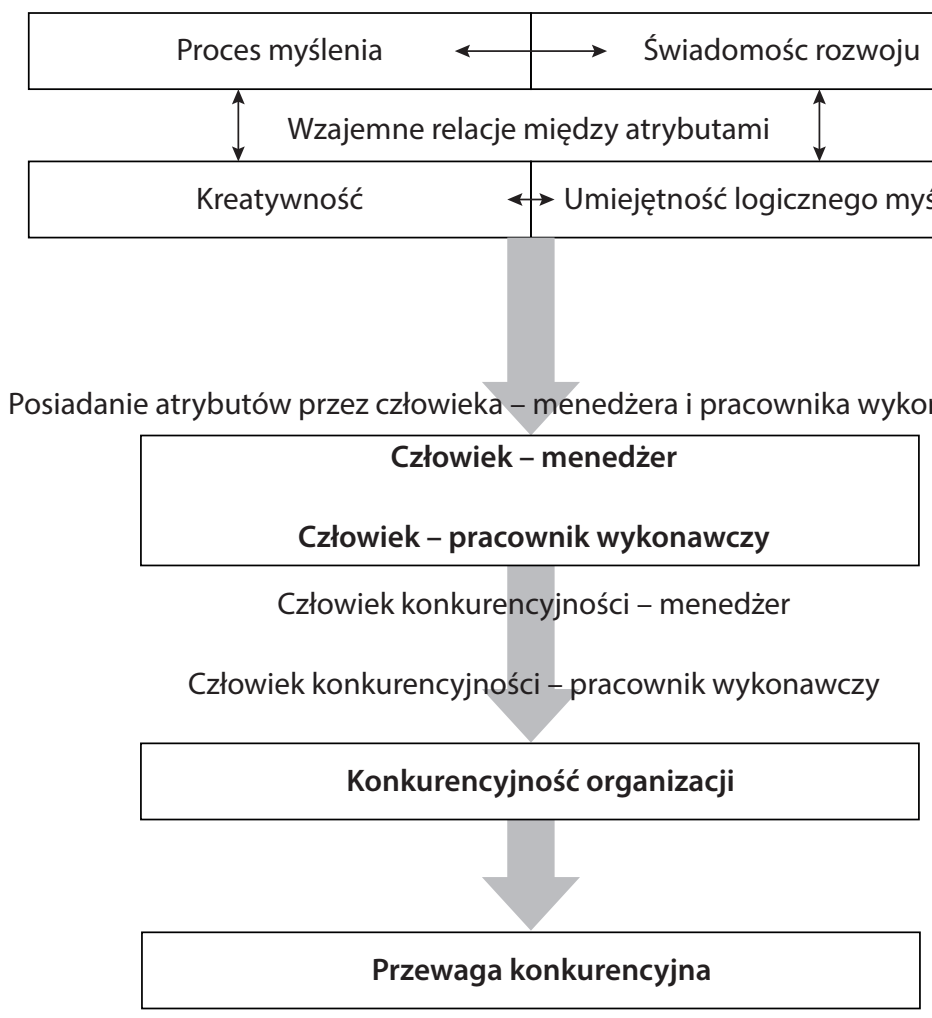

Rysunek 1. Podstawowe atrybuty człowieka-menedżera oraz człowieka-pracownika wykonawczego umożliwiające generowanie i kształtowanie konkurencyjności organizacji w osiągnięciu przewagi konkurencyjnej w koncepcji Leśniewskiego

Źródło: M.A. Leśniewski, Człowiek Konkurencyjności - model koncepcyjny, [w:] M. Budzanowska-Drzewiecka, K. Czernek (red.), Kierunki ewolucji nauk o zarzq̨dzaniu, Wydawnictwo Uniwersytetu Jagiellońskiego, Kraków 2018, s. 128.

Na rysunku 1 zostały zaprezentowane podstawowe atrybuty człowieka-menedżera oraz człowieka-pracownika wykonawczego. Atrybuty te stanowią fundament umożliwiający generowanie i kształtowanie konkurencyjności organizacji. Z punktu widzenia realizacji procesu zarządzania najważniejszą osobą jest menedżer. Dlatego on i jego podwładni (pracownicy wykonawczy) muszą tworzyć zgrany zespół, przyczyniający się do konkurencyjności organizacji. Można stwierdzić, że menedżerowie w sposób bezpośredni, a pracownicy wykonawczy w sposób pośredni przyczyniają się do generowania i kształtowania konkurencyjności. Każda organizacja powinna cenić menedżerów i pracowników wykonawczych, dbać o nich, bo dzięki nim może osiągnąć przewagę konkurencyjną. Proces myślenia, świadomość rozwoju, umiejętność logicznego łączenia oraz kreatywność mają stanowić nierozerwalne ogniwa, których jakość będzie miała wpływ na generowanie 
i kształtowanie konkurencyjności. Między tymi atrybutami ma zachodzić wzajemna relacja i mają być względem siebie komplementarne. Człowiek posiadający te atrybuty będzie łatwiej i szybciej generował i kształtował konkurencyjność niż człowiek, który takich atrybutów nie będzie miał. Człowiek-menedżer oraz człowiek-pracownik wykonawczy posiadający prezentowane atrybuty stają się Człowiekiem Konkurencyjności, czyli osobą mającą podstawy do generowania i kształtowania konkurencyjności, która z kolei przekształca się w przewagę konkurencyjną. Koncepcja Człowieka Konkurencyjności została stworzona na gruncie zarządzania miękkiego, podkreślającego doniosłość znaczenia człowieka w organizacji (człowiek i jego perspektywa). Człowiek Konkurencyjności to osoba mająca atrybuty, które umożliwiają dostrzeganie czynników generujących i kształtujących konkurencyjność organizacji. Jest to osoba optymistycznie widząca organizację. Można stwierdzić, że ta koncepcja to nie tylko dorobek zarządzania miękkiego, ale również psychologii behawioralnej i psychologii pozytywnej. Koncepcja Człowieka Konkurencyjności ma swoje źródła w koncepcjach homo oeconomicus i homo faber oraz w jakości człowieka, gdzie z koncepcji homo oeconomicus czerpie przekonanie, że człowiek to istota rozumna, myśląca, racjonalna, kierująca się uzasadnionymi wyborami ekonomicznymi, a z koncepcji homo faber - że człowiek to istota wytwarzająca, tworząca, czyli człowiek pracy. Natomiast z jakości pochodzi stopień zaangażowania w wykonywaną pracę. Koncepcja Człowieka Konkurencyjności traktuje człowieka jako jednostkę myślącą, rozumną, dokonującą wyborów uzasadnionych ekonomicznie, a z drugiej strony jako jednostkę tworzącą, pracującą oraz reprezentującą sobą jakość. Dostrzeżenie zasadności istnienia koncepcji Człowieka Konkurencyjności opiera się w głównej mierze na logice samej koncepcji oraz powiązaniu jej z innymi koncepcjami ${ }^{11}$.

\section{Menedżer kultury organizacyjnej}

Tworzenie i kształtowanie (profilowanie) kultury organizacyjnej jest strategicznym procesem trwający kilka, a nawet kilkanaście lat. Procesy kształtowania kultury przebiegają poprzez akceptację rozwiązań, które pozwalają organizacji lepiej radzić sobie z trudnościami. Kulturę organizacyjną tworzą wszyscy pracownicy, czyli kadra zarządzająca (menedżerowie) oraz pracownicy wykonawczy (podwładni). Można stwierdzić, że kształtowanie kultury organizacyjnej odbywa się w sposób bezpośredni (przez menedżerów z punktu widzenia realizacji procesu zarządzania) i pośredni (przez podwładnych jako biorców decyzji wydawanych przez menedżerów). Ważne, aby menedżerowie i podwładni tworzyli jedność organizacji,

11 Tamże, s. 129. 
czyli jedność kultury organizacyjnej. Na kadrze menedżerskiej spoczywa zadanie upowszechniania określonych sposobów zachowań (behawioralności), przy wykorzystaniu przyjętych przez nią rozwiązań organizacyjnych, technologicznych czy marketingowych (np. traktowanie pracowników jako klientów wewnętrznych danego przedsiębiorstwa - organizacji). Podstawowym warunkiem spopularyzowania pożądanych postaw jest tworzenie nie tylko określonych wzorców zachowań, lecz także mechanizmów sprzyjających ich wdrażaniu. Pracownicy, którym należy uzmysłowić atrakcyjność nowych wzorów zachowań, powinni sami znaleźć odpowiednie sposoby ich realizacji, a zadaniem kadry jest aktywne wpływanie na postępowanie podwładnych.

W zakresie oddziaływania menedżera na kulturę organizacyjną istnieją dwa główne procesy, tj. tworzenie oraz kształtowanie. Tworzenie to zapoczątkowanie kultury w organizacji, natomiast kształtowanie (profilowanie) to nadawanie takich cech, dzięki którym kultura organizacyjna osiąga kierunek, któremu można nadać określoną nazwę (np. kultura klanu, kultura hazardu, kultura władzy czy kultura zaufania). Każdy profil ma swoje specyficzne cechy. Samo tworzenie kultury organizacyjnej jest charakterystyczne dla nowo powstających organizacji, w których w miarę upływu czasu następuje również proces kształtowania. Organizacje już działające, funkcjonujące (np. kilka lat) na rynku bardziej skupiają się na kształtowanie kultury organizacyjnej. Należy podkreślić, że wszyscy pracownicy są włączeni w kulturę organizacyjną, natomiast w ujęciu szczegółowym to menedżerowie bezpośrednio uczestniczą w tworzeniu i kształtowaniu kultury organizacyjnej, z punktu widzenia realizacji procesu zarządzania daną organizacją ${ }^{12}$.

Przy tworzeniu i kształtowaniu kultury organizacyjnej należy wziąć pod uwagę kulturę osobistą menedżerów i podwładnych - to, z jakich kręgów kulturowych się wywodzą, ma wpływ na kulturę organizacyjną. Proces tworzenia kultury organizacyjnej z punktu widzenia zarządzania jest realizowany przez menedżerów i ich kultury osobiste ukształtowane poprzez kręgi kulturowe, w jakich oni znajdowali się lub znajdują. Kształtowanie kultury organizacyjnej odbywa się poprzez przenikanie czynników ${ }^{13} \mathrm{z}$ otoczenia wewnętrznego i zewnętrznego ${ }^{14}$. Do czynników wewnętrznych można zaliczyć cechy osobowościowe członków organizacji, tradycje kulturowe, istniejące rozwiązania organizacyjne, wpływy kadry menedżerskiej. Wszystkie one tworzą trudny do rozdzielania splot wzajemnych zależności, których rezultatem jest określona kultura organizacyjna jako kultura matka oraz

12 Tamże, s. 128-129.

13 Przenikliwość czynników, czyli przenikanie czynnika z otoczenia wewnętrznego i przenikanie czynnika z otoczenia zewnętrznego.

14 M. Bratnicki, W. Dyduch, Przedsiębiorczość - element kultury organizacyjnej, „Zarządzanie Zasobami Ludzkimi” 2002, nr 3-4, s. 81-92. 
subkultury organizacyjne jako kultury córki ${ }^{15}$. Kultura organizacyjna kształtowana jest w kontekście kultury narodowej, przy czym organizacja w pewien sposób modyfikuje kulturę, tak aby mogła ona w pełni wpisać się w rozwój danej jednostki (organizacji). Czynnikami zewnętrznymi kształtowania kultury organizacyjnej są między innymi stakeholders, stopa inflacji, stopa bezrobocia, zaawansowanie technologiczne danego kraju, szeroko pojęty wymiar społeczno-ekonomiczny danego państwa itp.

Kultura organizacyjna jest rezultatem określonego etapu rozwoju cywilizacyjnego, a także sposobu oddziaływania kadry zarządzającej. Menedżer nie tylko kształtuje kulturę organizacyjną, ale także może kształtować kulturę osobistą podwładnych (zawodową kulturę osobistą podwładnych). Można stwierdzić, że kształtowanie kultury organizacyjnej odbywa się między innymi poprzez kształtowanie kultur osobistych podwładnych, następuje przez wzajemne oddziaływanie menedżerów na kultury osobiste podwładnych. Na kulturę organizacyjną - czy to w procesie tworzenia, czy w procesie kształtowania - trzeba patrzeć holistycznie, czyli całościowo, dostrzegając wpływ czynników wewnętrznych i zewnętrznych wraz z kulturami osobistymi samych menedżerów i podwładnych.

\section{Menedżer konkurencyjności i przewagi konkurencyjnej}

Menedżer to osoba realizująca proces zarządzania sprawnie, skutecznie i efektywnie, przybliżając organizacji osiągnięcie założonego celu ${ }^{16}$. Menedżer musi stworzyć pozytywne relacje z podwładnymi (pracownikami wykonawczymi) oraz być źródłem dobrostanu organizacyjnego. Ze względu na odpowiedzialność za realizację procesu zarządzania organizacją jest on źródłem konkurencyjności (czynników konkurencyjności) i przewagi konkurencyjnej. Taki menedżer musi mieć określone umiejętności ${ }^{17}$.

15 Cz. Sikorski, Kultura organizacyjna. Efektywnie wykorzystaj możliwości swoich klientów, Wydawnictwo C.H. Beck, Warszawa 2006, s. 38.

16 S. Cyfert, K. Krzakiewicz, System celów menedżerów - postulat kreowania czy niszczenia wartości?, [w:] S. Rudolf (red.), Ekonomiczne i społeczne problemy nadzoru korporacyjnego, Wydawnictwo Uniwersytetu Łódzkiego, Łódź 2004, s. 173-185.

17 M. Baran, Ksztattowanie decyzji menedżerskich pod wpływem rozwiqzań systemowych w zakresie zarzq̨dzania informacjami, [w:] P. Łebkowski (red.), Innowacyjno-efektywnościowe problemy teorii i praktyki zarzq̨dzania, Uczelniane Wydawnictwo Naukowo-Dydaktyczne Akademii Górniczo-Hutniczej im. Stanisława Staszica, Kraków 2009, s. 185-191. 
Do najważniejszych umiejętności menedżera konkurencyjności i przewagi konkurencyjnej - w myśl koncepcji Kiełtyki - można zaliczyć18:

- umiejętność systemowego myślenia;

- umiejętności analityczne i diagnostyczne;

- umiejętności koncepcyjne;

- umiejętność działania w wielokulturowym otoczeniu;

- gotowość do ciągłej nauki;

- umiejętności interpersonalne;

- predyspozycje samodzielnego prowadzenia podmiotu gospodarczego.

Powyższe umiejętności nie wyczerpują listy tych, jakie powinien mieć menedżer konkurencyjności i przewagi konkurencyjnej. W koncepcji Leśniewskiego do umiejętności menedżera konkurencyjności i przewagi konkurencyjnej zalicza się również:

- umiejętność myślenia abstrakcyjnego ${ }^{19}$;

- umiejętność myślenia puzzlowego ${ }^{20}$;

- umiejętność tworzenia pomostu między nauką a praktyką gospodarczą oraz praktyką gospodarczą a nauką (transfer wiedzy)

- umiejętność permanentnego nabywania nowych umiejętności ${ }^{22}$.

Na podstawie przedstawionych powyżej umiejętności można stwierdzić, że nie każdy menedżer nadaje się na menedżera konkurencyjności i przewagi konkurencyjnej ze względu na brak określonych umiejętności. Kształtowanie konkurencyjności i przewagi konkurencyjnej jest działaniem wymagającym od menedżerów inteligentnego wykorzystywania myślenia do bycia lepszym niż konkurenci.

18 L. Kiełtyka, Rola menedżera we współczesnych organizacjach, „Przegląd Organizacji” 2016, nr 8(919), s. 4-11.

19 Myślenie abstrakcyjne przejawia się w zdolności uogólniania, wyróżniania związków, podobieństw między przedmiotami. Dotyczy również wychodzenia poza główne znaczenia danych pojęć. Myślenie abstrakcyjne to myślenie o czymś w innych, nieznanych dotąd formach.

20 Myślenie puzzlowe zmierza w kierunku umiejętności logicznego dostrzegania fragmentów tworzących obraz danej rzeczywistości. Osoba cechująca się myśleniem puzzlowym widzi daną rzeczywistość składającą się z pojedynczych elementów tworzących logiczność catość.

21 Nauka a praktyka gospodarcza to wkład nauki do praktyki gospodarczej różnych organizacji, natomiast praktyka gospodarcza a nauka to wkład praktyki do nauki. Między nauką i praktyką gospodarczą i na odwrót musi być stworzony pomost (transfer wiedzy), aby dwa układy ważne dla gospodarki narodowej, międzynarodowej czy globalnej mogły koegzystować.

22 Permanentne nabywanie nowych umiejętności to szukanie przez człowieka możliwości do zdobywania takich umiejętności, których dana osoba jeszcze nie ma, a umiejętności te będą przydatne w dalszym rozwoju jej i organizacji. 
Można stwierdzić, że menedżer, konkurencyjność i przewaga konkurencyjna 23 tworzą nierozerwalny logiczny ciąg działań (rysunek 2).

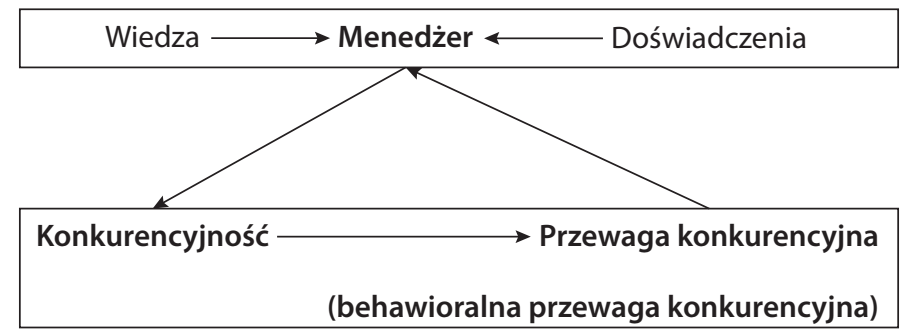

Rysunek 2. Menedżer a konkurencyjność i przewaga konkurencyjna - menedżer konkurencyjności i przewagi konkurencyjnej

Źródło: opracowanie własne na podstawie: M.A. Leśniewski, Świadomość ekorozwojowa w konkurencyjności miękkiej przedsiębiorstw, „Edukacja Ekonomistów i Menedżerów” 2016, nr 2(40), s. 115-134; M.A. Leśniewski, Behawioralna kulturowa przewaga konkurencyjna przedsiębiorstw, [w:] J. Kaczmarek, P. Litwa (red.), Procesy rozwoju przedsiębiorstw w konkurencyjnym i innowacyjnym otoczeniu, Fundacja Uniwersytetu Ekonomicznego, Kraków 2016, s. 123-135; M.A. Leśniewski, Pozytywny menedżer wiedzy decydentem stymulowania rozwoju zasobów przedsiębiorstwa, „Akademia Zarządzania” 2018, nr 2(1), s. 81-100.

Jak zaprezentowano na rysunku 2, punktem wyjścia do kształtowania konkurencyjności i przewagi konkurencyjnej jest menedżer wraz ze swoją nabytą i nabywaną wiedzą oraz nabytymi i nabywanymi doświadczeniami. Konkurencyjność i przewaga konkurencyjna spoczywają głównie w rękach menedżerów najwyższego szczebla zarządzania (top management), ale trzeba pamiętać, że również menedżerowie niższych szczebli mają swój udział w konkurencyjności i przewadze konkurencyjnej. Menedżer kształtuje czynniki konkurencyjności - proces ten polega na ich ukierunkowaniu na określoną formę, jak na przykład konkurencyjność miękka, konkurencyjność twarda czy konkurencyjność mieszana (miękko-twarda). Kształtowanie tych czynników opiera się na mechanizmie merytoryczno-doświadczeniowym, czyli tym, jaką wiedzę i doświadczenia w tym zakresie ma dany menedżer. Jeśli menedżer opiera konkurencyjność na zaufaniu, motywacji czy kulturze organizacyjnej, to w przedsiębiorstwie będzie kształtować raczej konkurencyjność miękką (lub zbliżoną do miękkiej). Natomiast jeśli menedżer będzie bardziej promował konkurencyjność opartą na budynkach, wyposażeniu czy pieniądzach, wówczas będzie kształtować raczej konkurencyjność twardą. Konkurencyjność jest po to kształtowana, aby przedsiębiorstwo osiągnęło na rynku przewagę konkurencyjną, dzięki której będzie dalej się rozwijać. Przewaga konkurencyjna

23 W koncepcji Leśniewskiego przewaga konkurencyjna ma charakter behawioralny, stąd druga nazwa behawioralna przewaga konkurencyjna. 
zostanie osiągnięta wówczas, kiedy czynnik lub czynniki konkurencyjności zadziałają na rynku i organizacja otrzyma korzyści z tego płynące ${ }^{24}$. Trzeba mieć świadomość, że nie wszystkie czynniki konkurencyjności tworzą przewagę konkurencyjną - tylko część z nich tworzy określone podstawy, warunki, aby inne czynniki mogły zadziałać na rynku. Na konkurencyjność należy patrzeć przez pryzmat rodzajów czynników. Osiągnięta przewaga konkurencyjna tworzy określone zachowanie organizacji na rynku względem innych uczestników, oznacza to, że przewaga konkurencyjna ma postać przewagi behawioralnej. Tak jak strategia tworzy zachowanie organizacji (strategia behawioralna), tak samo przewaga konkurencyjna jest behawioralną przewagą konkurencyjną. Osiągnięta behawioralna przewaga konkurencyjna kształtuje zachowanie menedżera, który wyciąga wnioski, uczy się, nabywa doświadczenia jak kształtować konkurencyjność, aby doskonalić przedsiębiorstwo pod kątem osiągnięcia jeszcze większej przewagi konkurencyjnej.

Menedżer konkurencyjności i przewagi konkurencyjnej musi stale monitorować kształtowanie czynników konkurencyjności oraz przewagi konkurencyjnej (behawioralnej przewagi konkurencyjnej). Konkurencyjność i przewaga konkurencyjna podlegają ciągłym zmianom. To, co dziś tworzy konkurencyjność i przewagę konkurencyjną, jutro już nie wpływa na nią. Każda organizacja i każde przedsiębiorstwo oparte na rynkowych zasadach uczestniczenia w gospodarce powinno zadbać o takiego menedżera, który w sposób sprawny, skuteczny i efektywny będzie kształtować konkurencyjność z zamiarem osiągnięcia behawioralnej przewagi konkurencyjnej.

\section{Podsumowanie}

Konkurencyjność i kultura organizacyjna stanowią dwa nierozerwalne komponenty rozwoju przedsiębiorstwa. Konkurencyjność nie tylko opiera się na rzeczowych elementach majątku, ale również - a może przede wszystkim - na elementach niematerialnych i miękkich, czyli kulturze organizacyjnej. Przedstawione w niniejszym opracowaniu powiązanie konkurencyjności i kultury organizacyjnej w postaci konkurencyjności kulturowej przedsiębiorstw wskazuje na duży stopień złożoności poruszanego problemu badawczego. Konkurencyjność kulturowa jest pochodną problemów wynikających z uwarunkowań kulturowych, a także z konkurencyjności przedsiębiorstw. Poruszany problem badawczy stanowi interdyscyplinarne podejście do badania konkurencyjności i kultury organizacyjnej. Rozwiązanie problemów konkurencyjności kulturowej jest uzależnione

24 M. Baran, Skuteczność utrzymywania strategicznej przewagi konkurencyjnej przez liderów branży budowlanej w świetle kryzysu w otoczeniu gospodarczym, [w:] M. Baran (red.), Poszukiwanie przewagi konkurencyjnej. Wybrane uwarunkowania, Wydawnictwo Uniwersytetu Jagiellońskiego, Kraków 2014, s. 139-154. 
od postępów badań teoretycznych i empirycznych samej konkurencyjności i kultury organizacyjnej. Koncepcja konkurencyjności kulturowej ma przyczyniać się do obrania jednej z dróg osiągnięcia przewagi konkurencyjnej przez podmiot gospodarczy. Przydatność konkurencyjności kulturowej dla ludzi nauki i praktyków gospodarczych jest istotna jako inne spojrzenie na konkurencyjność i kulturę organizacyjną w osiąganiu przewagi konkurencyjnej.

Głównym punktem konkurencyjności kulturowej z perspektywy procesu zarządzania jest menedżer jako decydent, a punktem kolejnym jest podwładny (pracownik wykonawczy). Menedżer wraz z podwładnym tworzą zwarte ogniwo konkurencyjności kulturowej. Dlatego bardzo istotne jest to, jakich menedżerów i podwładnych zatrudnia przedsiębiorstwo.

Niniejsze opracowanie stanowi otwarcie dyskusji w świecie nauki i praktyki gospodarczej nad konkurencyjnością kulturową przedsiębiorstw.

Bibliografia

Baran M., Ksztattowanie decyzji menedżerskich pod wptywem rozwiq̨zań systemowych w zakresie zarzqdzania informacjami, [w:] P. Łebkowski (red.), Innowacyjno-efektywnościowe problemy teorii i praktyki zarzqdzania, Uczelniane Wydawnictwo Naukowo-Dydaktyczne Akademii Górniczo-Hutniczej im. Stanisława Staszica, Kraków 2009, s. 185-191.

Baran M., Skuteczność utrzymywania strategicznej przewagi konkurencyjnej przez liderów branży budowlanej w świetle kryzysu w otoczeniu gospodarczym, [w:] M. Baran (red.), Poszukiwanie przewagi konkurencyjnej. Wybrane uwarunkowania, Wydawnictwo Uniwersytetu Jagiellońskiego, Kraków 2014, s. 139-154.

Bratnicki M., Dynamizowanie procesu zarzq̨dzania: organizacyjny pierwowzór przedsiębiorczości, [w:] Dynamika zarządzania organizacjami. Paradygmaty - metody - zastosowania: księga pamiq̨tkowa wydana z okazji 50-lecia pracy naukowej prof. zw. dr. hab. Jerzego Rokity, Wydawnictwo Akademii Ekonomicznej im. Karola Adamieckiego w Katowicach, Katowice 2007, s. $107-121$.

Bratnicki M., Dyduch W., Przedsiębiorczość - element kultury organizacyjnej, „Zarządzanie Zasobami Ludzkimi" 2002, nr 3-4, s. 81-92.

Cyfert S., Krzakiewicz K., System celów menedżerów - postulat kreowania czy niszczenia wartości?, [w:] S. Rudolf (red.), Ekonomiczne i społeczne problemy nadzoru korporacyjnego, Wydawnictwo Uniwersytetu Łódzkiego, Łódź 2004, s. 173-185.

Czakon W., Sieci w zarzq̨dzaniu strategicznym, Wolters Kluwer Polska, Warszawa 2012.

Kiełtyka L., Rola menedżera we wspótczesnych organizacjach, „Przegląd Organizacji” 2016, nr 8(919), s. 4-11.

Leśniewski M.A., Behawioralna kulturowa przewaga konkurencyjna przedsiębiorstw, [w:] J. Kaczmarek, P. Litwa (red.), Procesy rozwoju przedsiębiorstw w konkurencyjnym i innowacyjnym otoczeniu, Fundacja Uniwersytetu Ekonomicznego, Kraków 2016, s. 123-135.

Leśniewski M.A., Człowiek Konkurencyjności - model koncepcyjny, [w:] M. Budzanowska-Drzewiecka, K. Czernek (red.), Kierunki ewolucji nauk o zarzq̨dzaniu, Wydawnictwo Uniwersytetu Jagiellońskiego, Kraków 2018, s. 123-135. 
Leśniewski M.A., Konkurencyjność kulturowa przedsiębiorstw. Studium teoretyczno-empiryczne, Wydawnictwo Uniwersytetu Jana Kochanowskiego w Kielcach, Kielce 2020.

Leśniewski M.A., Konkurencyjność miękka przedsiębiorstw, Wydawnictwo Difin, Warszawa 2015.

Leśniewski M.A., Konkurencyjność przedsiębiorstw. Wybrane problemy, Towarzystwo Naukowe Organizacji i Kierownictwa „Dom Organizatora”, Toruń 2011.

Leśniewski M.A., Pozytywny menedżer wiedzy decydentem stymulowania rozwoju zasobów przedsiębiorstwa, „Akademia Zarządzania” 2018, nr 2(1), s. 81-100.

Leśniewski M.A., Świadomość ekorozwojowa w konkurencyjności miękkiej przedsiębiorstw, „Edukacja Ekonomistów i Menedżerów" 2016, nr 2(40), s. 151-164.

Sikorski Cz., Kultura organizacyjna. Efektywnie wykorzystaj możliwości swoich klientów, Wydawnictwo C.H. Beck, Warszawa 2006.

Stańczyk S., Nurt kulturowy w zarzq̨dzaniu, Wydawnictwo Uniwersytetu Ekonomicznego we Wroctawiu, Wroctaw 2008.

Sutkowski Ł., Kulturowe procesy zarządzania, Wydawnictwo Difin, Warszawa 2012.

\section{Streszczenie}

Problem konkurencyjności stanowi wielkie wyzwanie nie tylko dla praktyki gospodarczej przedsiębiorstw, ale również dla nauk zarządzania i jakości. Konkurencyjność stanowi nierozerwalny element (czynnik) związany z osiągnięciem i utrzymaniem przewagi konkurencyjnej na rynku. Może być postrzegana jako ogół czynników (np. wszystkie zasoby organizacji) tworzących podmiot gospodarczy lub jako wybrany czynnik (np. kultura organizacyjna), dzięki któremu organizacja osiągnie i będzie utrzymywać przewagę konkurencyjną. Celem opracowania jest przedstawienie konkurencyjności widzianej przez pryzmat kultury organizacyjnej. Rozważania przedstawione w niniejszym rozdziale oparte są na interpretacyjnym studium literatury przedmiotu. Powiązanie konkurencyjności i kultury organizacyjnej w pełni wpisuje się w przedmiot zainteresowań zarządzania miękkiego i konkurencyjności miękkiej.

Słowa kluczowe: konkurencyjność, kultura organizacyjna, konkurencyjność miękka

\section{Competitiveness seen through the prism of corporate organizational culture - a theoretical study}

\section{Abstract}

The problem of competitiveness is a great challenge not only for the business practice of enterprises but also for management and quality sciences. Competitiveness is an inseparable element (factor) related to achieving and maintaining competitive advantage on the market. It can be perceived as the total of factors (e.g. all the resources of an organization) constituting an economic entity or as a selected factor (e.g. organizational culture), thanks to which the organization will achieve and maintain a competitive advantage. The aim of the study is to present in the theoretical sphere of competitiveness seen through the prism of organizational culture. The considerations presented in this study are based on an interpretative study of the literature on the subject. The combination of competitiveness and organizational culture is fully in line with the interests of soft management and soft competitiveness.

Keywords: competitiveness, organizational culture, soft competitiveness 